Indonesian Journal of EFL and Linguistics

Vol. 1 No. 2, 2016

eISSN: 2503-4197, pISSN: 2527-5070

www. indonesian-efl-journal.org

DOI: http://dx.doi.org/10.21462/ijefll.v1i2.13

\title{
Enhancing Students' Reaction Writing via Short Stories: A Pedagogical Perspective
}

\author{
Ainon Omar \\ Sultan Idris Education University, Malaysia \\ e-mail: ainon@fbk.upsi.edu.my \\ Ezatul Marini Mohd. Ghazali \\ Sultan Azlan Shah Polytechnic, Malaysia \\ e-mail: ezatul_marini@psas.edu.my
}

\begin{abstract}
:
Studies have shown that literary texts such as short stories have been able to develop students' interpretative skills as well as provide opportunities for students to enhance their critical thinking skills. This study aimed at investigating the use of short stories on enhancing students' reaction writing. The purpose of the study was to look into a new method that can assist students in expressing their views and opinions about current issues. Thus, a study was conducted to investigate whether the use of short stories as an authentic material can assist students in enhancing their reaction writing. An experimental study was employed on a group of technical students. A pre-test was administered followed by treatment sessions and finally a post-test before a semi-structured interview was conducted on lecturers. The study gathered data on the lecturers' perceptions towards the idea of incorporating literary texts in their English language lessons. The findings showed that the use of the short story had assisted students to generate ideas to write their reaction paper although a lot of guidance had to be given by the lecturer. The students as well as the lecturers were optimistic on the idea of incorporating literature in the English language course. However, the choice of literary texts needs to be carefully selected and also students' interests and needs are taken into consideration in order for them to write their reaction paper.
\end{abstract}

Keywords: reaction writing, literary texts, language learning, interpretive skills

Indonesian Journal of EFL and Linguistics, Vol. 1 (2), 2016 


\section{INTRODUCTION}

The use of literary texts is known to have multiple benefits for learners in the English language classroom (Collie \& Slater, 1987; Duff and Maley 1992; Lazar 1993, Erkaya, 2005; Chiang, 2007). Collie and Slater (1987), Duff and Maley (1992), Lazar (1993), Erkaya (2005) and Chiang (2007) revealed that using literary texts as a language teaching resource can be beneficial in developing students' language development, personal growth and cultural enrichment. Through the incorporation of the literature component in the language instruction certain language skills among language learners, especially in developing their reading and writing skills can be enhanced (Saraceni, 2007). Short stories are suitable for classroom use as the length is manageable and there is a wide range of choices to choose from depending on students' interest and proficiency level ( Erkaya, 2005; Chiang, 2007). Besides that, through the utilisation of short stories learners' interpretative skills can be developed using the Reader Response Theory (Sanchez, 2009) which provides them with ample opportunities to voice their views and opinions. Since reaction writing involves students identifying the author's main ideas and main supporting evidence, as well as stating their own responses to those ideas backed by their own evidence and thinking, therefore, using literary texts such as short stories would be a good resource to exploit in the English language classroom. The ability for the students to interpret the multiple meanings in the texts and express their views would assist the students in improving their reaction writing skills.

As such, this paper examined the potential of using short stories in enhancing students' ability to express their views and opinions when writing a reaction paper. It is hoped that the study will help language educators in understanding the advantages of incorporating literature especially short stories in their English language lessons.. The study also aimed at exposing the potential of using short stories in language teaching so that students' ability in understanding the meaning as well as interpreting and reacting to the text will be better enhanced and developed.

\section{LITERATURE REVIEW}

It is very important for educators to understand the importance of incorporating literature component in the language instruction as well as its usefulness in enhancing certain language skills among language learners, especially in developing their reading and writing skills (Saraceni, 2007). In the Malaysian Education system, literature has been taught as a subject or used as a means of learning English language from independence to date (Curriculum Development Centre, 2003). Though the Malaysian education has experienced several waves of change in the medium of instruction regarding the use of language, continuous efforts have been carried out in developing students' English language competency, where various literature-based reading programmes were implemented at primary and secondary levels (Ganakumaran, 2003). The incorporation of a tested literature component in the secondary school English syllabus made the point that the study of literature benefits language learners. Thus, the inclusion of literature component or as suggested by Rosenblatt (1985) to teach literature as aesthetic experience should be 
included in the English Courses in tertiary level so that students can be further guided and exposed to the "beauty" of appreciating literature for the purpose of enriching their language competencies as well as developing their creativity especially in communicating as in voicing out their views and opinions be it orally or in written form ( Ganakumaran, Shahizah \& Koo, 2003). In addition, the students' ability to be critical in their interpretations will assist them in writing their reaction paper as a reaction paper requires a close reading of the text that goes beyond the surface meaning. Students are required to imply on the ideas presented, evaluate and analyse the author's purpose and main points (Scoggins, 2015).

According to Chiang (2007 as cited in Khatib \& Nasrollahi, 2012) mentioned that using literature as an authentic source in language classes provides ample opportunities for students to practice as well as improve the four language skills. His views was supported by Stern (2001) who points out that literature can be an being an ideal source for writing tasks as ideas and views can be generated through discussions on the different elements of literary texts such as characters, plots and themes. Chiang (2007as cited in Khatib \& Nasrollahi, 2012) further reiterates that appropriate exploitation of short stories can provide quality text content which can further enhance learners' proficiency level. In his talk during a seminar on Literature \& English Language Education, Ganakumaran (2012), discussed on why the education system keeps bringing back literature into the syllabus. It was due to the fact that literature is 'a question minus the answer' where it helps students to generate discussion, controversy and critical thinking. There are extensive reasons of why literature should be incorporated in the language classroom as pointed by Ganakumaran (2012). Some of the reasons that may perfectly fit the objectives of this study are that literature develops perceptive and interpretative thinking skills and by using literary materials, students' existing thoughts are challenged as they are required to understand, interpret and analyse the texts that are provided to them. Thus, these will promote genuine communication of ideas among students. Chiang (2007, p. 170) mentioned "Literary texts are often rich is multiple layers of meaning, and can be effectively mined for discussions. While literature has the potential to be a tool of great use in L2 classrooms, its potential can be best realized when readers are encouraged to develop personal responses to the reading from multiple aspects and to share them in discussions". Through the use of short stories, and the teaching of literature, students will experience rich and diverse exposure to language where they are encouraged to reflect and react to the materials in response to their understanding and perspectives. This in turn would enhance the students' critical thinking so that they can voice their opinions and views about certain issues when they write their reaction paper.

A study was conducted by Sivapalan and Ganakumaran (2008) to investigate the perceptions, attitudes and perceived needs of young adult technical learners towards the incorporation of literature in their English programme. It was found that technical learners are somewhat optimistic of the incorporation of literature in the English programme offered to them. However it is imperative to make the literature learning experience meaningful and relevant to them by the use of appropriate 
literary texts and the incorporation of technology in the literature classroom. Another study was done by Traore (2008) on using literature with Business and Medical English students which proved the notion that literature is irrelevant to engineering students contradicted the findings of the study. The findings indicated that adolescent engineering students perceived that literature is important in developing their reading ability. The study also showed that engineering students preferred reading short stories rather than novels, plays or poems. The study also suggested that engineering students preferred reading contemporary texts rather than classic texts.

Erkaya (2005) notes four benefits of using of short stories to teach ESL/EFL, i.e. motivational, literary, cultural and higher-order thinking benefits. There are several advantages of using short stories in the language classroom. Their practical length can be the most revealing reason which allows the students to conclude the task of reading in one sitting (de Silva, 2001). This criteria fits the requirement of the type of literary materials to be used in the language lesson especially with tertiary level students who are always worried about the amount of work they need to perform and at most times have the feeling of being overwhelmed by the amount of work they have to complete. The use of short stories can be seen as less frightening since students will not be intimidated by the length and number of pages of the text that they are required to read.

Reader Response Theory offers limitless ways as to how a text can be explored especially in Malaysian teaching and learning context (Shahizah, Nackeeran, 2003). Tucker (2000) in his article, Liberating Students through Reader-Response Pedagogy in the Introductory Literature Course, concurs that the reader-response approach allows students more latitude in responding to what they read and encourages varied responses. A reader-response approach focuses on students' individual responses to text and how he or she brings meaning to the text through his or her interpretative skills (Galda \& Liang, 2003). Ross C. Murfin in Tucker (2000) explains that Reader Response criticism focuses on what texts do to - or in- the mind of the reader, rather than regarding a text as something with properties exclusively its own.This approach enables students to experience relevance in the reading task, involves them in an active, not passive, encounter with the literature, validates them as critical readers who are capable of determining meaning in texts, and provides them with the opportunity to express themselves freely (Tucker, 2000).

In his study on the application of reader-response theory in producing reading logs, Carlisle (1999) proved that the theory can be a practical way for students to develop their individual responses towards the novel that they are reading. Students were able to communicate their personal thoughts and views as they wrote in their entries discussing on the novel or its literary elements. Therefore, it is possible to apply this theory in developing the ability to write a reaction paper since students will be able to gain clearer understanding of the ideas in the short story, and will enjoy having the space to express their own feelings and hopefully by carrying out the study, students will value the oral discussion activities, thus their writing and critical thinking skills can be improved. 


\section{RESEARCH METHODOLOGY}

This study employed the experimental research design where it tested a stimulus to determine whether it influenced an outcome (Creswell, 2008). In this study, the researcher experimented on the use of a short story in an English language class, and later tested whether the use of a short story helped in enhancing the students' ability to write a reaction paper. The selected samples for the study were 27 technical students and 19 English language Lecturers from a technical College. The technical students were chosen based on purposive sampling as the the technical students normally learnt English based on their technical background. Also, their lecturers revealed in an informal interview that the technical students seem to have difficulties in expressing their opinions or views about current issues.

The researcher chose two short stories for the study based on probable interest to the students, and level of difficulty (Galda, Cullinan, \& Sipe, 2010). All three stories were similar in length and had almost the same readability level. The two stories used during the experimental weeks were "Angry" by Catalina Rembuyan and "The Stalker Within" by Sabarina bt Abu Bakar. The lecturer and the students involved in the study had not read the two stories prior to the study.

After reading the story, the subjects were required to write a hundred and twenty (120) words reaction paper and the researcher evaluated the papers based on a predetermined set of criteria. The researcher also referred to the rubrics for reaction paper which was prepared by the course coordinator of English Language Course. The researcher then identified any lack of element that may affect the quality of reaction paper produced by the subjects. The researcher planned and carried out three (3) sessions of treatments. The researcher again used the short story entitled "Angry" by Catalina Rembuyan. Each session was carried out within ninety (90) minutes of face to face session. In each session, the researcher guided and carried out activities that aided the subjects to focus on dealing with important elements of writing a reaction paper i.e summary or synopsis, analysis or evaluation, and reactions. During each stage, subjects were required to answer several questions that later helped them in writing the actual reaction paper. At the end of each session, subjects were assigned to submit a paragraph consisting of the points for the stages that they had dealt with. Upon the completion of the three sessions, subjects produced a complete piece of reaction paper covering the three main elements of summarizing, analysing and reacting to the short story that they have read. The researcher used a short story entitled "The Stalker Within" by Sabarina bt. Abu Bakar for the post-test session. Subjects were required to read the text and later write a reaction paper. By referring to the checklist and the rubric, the papers were evaluated and analysed to mark any progress in the students' work compared to the pre-test task.

The researcher utilised a set of questionnaire to all English language lecturers. Items from the questionnaire were tabulated in the form of percentages to gauge the lecturers' perceptions of using the short stories in their English language course. Items on the lecturers' perceptions and attitudes on their experiences in teaching and learning of literature were identified. This is followed by an interview on their 
perceptions and attitudes towards the use of literary materials as resources in teaching English in polytechnic's level. Their oral feedback during the interview were added in the discussion to further strenghten the points of a particular issue or section.

\section{Research Questions}

1. To what extent does the use of short story help to enhance students' reaction writing skills?

2. What are the English lecturers' perceptions on the use of short stories to enhance their students' reaction writing skills?

\section{FINDINGS}

To answer research question 1 , the researcher conducted a pre and post-test and analysed the students' reaction paper based on their summary, analysis and reaction. The researcher analysed the paper by looking at the sections produced by the respondents in their reaction paper. Based on the analysis, most of the respondents were ranged between low to intermediate level of proficiency. The analysis of the pre-test done by the researcher showed that $85.2 \%$ of the respondents only wrote their reactions without discussing the summary and analysis of the story that they read. This was followed by $7.4 \%$ of the respondents writing only the analysis and reaction sections without focusing on the summary. It was also found that $3.7 \%$ of the respondents only wrote the analysis of the short story and the remaining $3.7 \%$ focused on writing the summary and reaction without analysing the story that they read. Based on the analysis of pre-test, it can be concluded that the respondents were mainly focusing on writing their reaction without proper understanding of the importance of focusing on the summarising and analysing the material provided.

The researcher used a short story entitled The Stalker Within by Sabarina bt.Abu Bakar for the post-test session. Respondents are required to read the story and later write a reaction paper. By referring to the checklist and the rubric, the papers are evaluated and analysed to mark any progress in the students' work compared to the pre-test task. The findings of post test are explained in the table below.

Table 1: Analysis of Post-Test

\begin{tabular}{|c|c|c|c|}
\hline \multirow{2}{*}{ RESPONDENT } & \multicolumn{3}{|c|}{ REACTION PAPER } \\
\cline { 2 - 4 } & SUMMARY & ANALYSIS & REACTION \\
\hline 1 & $\checkmark$ & $\checkmark$ & $\checkmark$ \\
\hline 2 & $\checkmark$ & $\checkmark$ & $\checkmark$ \\
\hline 3 & $\checkmark$ & $\checkmark$ & $\checkmark$ \\
\hline 4 & $X$ & $X$ & $\checkmark$ \\
\hline 5 & $\checkmark$ & $\checkmark$ & $\checkmark$ \\
\hline 6 & $\checkmark$ & $\checkmark$ & X \\
\hline 7 & $\checkmark$ & $\checkmark$ & $\checkmark$ \\
\hline 8 & $\checkmark$ & $X$ & $\checkmark$ \\
\hline 9 & $\checkmark$ & $\checkmark$ & $\checkmark$ \\
\hline
\end{tabular}

Indonesian Journal of EFL and Linguistics, Vol. 1 (2), 2016 


\begin{tabular}{|c|c|c|c|}
\hline 10 & $\checkmark$ & $\checkmark$ & $\checkmark$ \\
\hline 11 & $\checkmark$ & $\checkmark$ & $\checkmark$ \\
\hline 12 & $\checkmark$ & $\checkmark$ & $\checkmark$ \\
\hline 13 & $\checkmark$ & $\checkmark$ & $\checkmark$ \\
\hline 14 & $\checkmark$ & $\checkmark$ & $\checkmark$ \\
\hline 15 & $\checkmark$ & $X$ & $\checkmark$ \\
\hline 16 & $\checkmark$ & $X$ & $\checkmark$ \\
\hline 17 & $\checkmark$ & $\checkmark$ & $\checkmark$ \\
\hline 18 & $\checkmark$ & $\checkmark$ & $\checkmark$ \\
\hline 19 & $\checkmark$ & $\checkmark$ & $\checkmark$ \\
\hline 20 & $\checkmark$ & $\checkmark$ & $X$ \\
\hline 21 & $\checkmark$ & $\checkmark$ & $X$ \\
\hline
\end{tabular}

The table above showed that out of 21 respondents ( $\mathrm{N}=21), 71.4 \%$ (15 respondents) were able to include the three fundamental characteristics of writing good reaction paper in completing their task. The remaining 6 respondents were unable to include at least one of the characteristics; $14.3 \%$ of the respondents (3 respondents) left out the analysis section, $9.5 \%$ of the respondents (2 respondents) left out the reaction and $4.8 \%$ (1 respondent) only wrote his reaction and left out the summary and analysis sections.

Research question 2 was based on a set of questionnaire prepared for the lecturers as respondents to get their perceptions and attitudes on the use of short story as literary resource in enhancing the reaction writing skills among technical students. The questionnaire was adapted from Ganakumaran \& Sivapalan (2008) questionnaires on the study of The Incorporation of Literature in the English Language Program for Engineering Students. A set of semi-structured interview protocol was also carried out with the respondents. The purpose of the interviews are to gather in-depth information on the use of short story to enhance students' ability in writing the reaction paper and also to gather the English lecturers views on the use of literary texts as teaching resources in the English language course.

The first item of the questionnaire aimed to look at the respondents' perceptions towards the idea of teaching and learning literature. The findings revealed that $31.3 \%$ of the respondents strongly agreed that learning literature can be enjoyable and $56.3 \%$ of the respondents agreed to the statement. Only $6.3 \%$ of the respondents respectively disagreed and strongly disagreed that learning literature can be enjoyable. For the item: I like teaching literature, $43.8 \%$ of the respondents agreed to the statement where $12.5 \%$ of the respondents strongly agreed and $31.3 \%$ of the respondents agreed that they like teaching literature. However, 25\% of the respondents disagreed and $6.3 \%$ strongly disagreed that they like teaching literature, while $18.8 \%$ were indecisive. Based on the survey, $18.8 \%$ of the respondents strongly stated that they like using literary materials in their lesson and $25 \%$ agreed to the statement. However, $31.3 \%$ of the respondents disagreed that they like using literary materials and $25 \%$ remained indecisive. 
During the interview sessions, the interviewees were asked a question on the use of short story and video clip in enhancing the students to generate ideas in writing the reaction paper. Their responses were:

Interview Question: In your opinion, which is better in helping students to generate ideas in writing their reaction paper? Watching video clip or reading short story? Why?

L1: Video would better suit the students' level of English competency. It would be more suitable with their knowledge. However, by using short story, it can be a good start to promote writing skills among students

L2: Both video and short story have their pros and cons. When students are asked to generate ideas for writing they would get good ideas to write the reaction about the video. This is because they are so used to watching movies and dramas and talk about it and start giving comments about the show. However, problems do occur when the students could not write without any help of example text. When short stories are used, the students are guided throughout their writing section. The text can be referred at their own pace. Students can read and reread to get ideas.

Based on the findings of the survey, $62.5 \%$ of the respondents agreed that reading short story helped students in getting ideas to write reaction paper while $81.3 \%$ stated that viewing video clip helped students in getting ideas to write reaction paper.

The next item was the English Lecturers' perceptions on the teaching of literature as a subject or as a component. The findings revealed that only $25 \%$ of the respondents agreed to the statement: Literature should be a component of the syllabus for English courses taken by technical students in addition to grammar, reading, writing, listening and speaking skills, while $56.3 \%$ disagreed and $18.8 \%$ were indecisive.

Interview Question: Do you think literature should be made a teaching component to polytechnic's engineering students? Why?

L1: Literature can be made a teaching component but it depends on the materials used.

L2:It can be introduced as one topic in the module to make the students involved in reading especially in gauging their interests to read.

The item on the respondents' perceptions on the benefit of learning literature in helping students to improve their language skills revealed that $6.3 \%$ of the respondents strongly agreed that learning literature can help students improve their language skills and $68.8 \%$ agreed to the statement. However, $6.3 \%$ of the respondents strongly disagreed and another $6.3 \%$ disagreed while $12.5 \%$ of respondents were indecisive. 
The last item was to investigate the English lecturers' attitudes towards the incorporation of short story into the English language Course. $75.0 \%$ of the respondents agreed that the incorporation of short story into the English language Course would help technical students gained interest in literature. Only $6.3 \%$ of the respondents disagreed to the idea while $18.8 \%$ of the respondents remained indecisive. Based on the survey, $50.0 \%$ of the respondents agreed that the type of genre used in the literature class can affect technical students' interest to learn literature. On the other hand only $6.3 \%$ of the respondents strongly disagreed while an alarming $43.8 \%$ of the respondents chose to be indecisive. The interview with the lecturers revealed the following:

Interview Question: Do you think short story can be used as literary materials to be used in the English language Class?

L1: If we can get short story in the form of video, it would be a good start to introduce literature to technical students because based on the level of proficiency, to get students to read might be a challenge.

L2: Short story can be a good source to promote reading among technical students. When stories are given, students can get the interest to read. Indirectly, they pick new words, and sentences that would help them in understanding the language. Reading will later increased their speaking ability.

Based on the survey and interviews done, though most of the lecturers learnt how to teach literature during their tertiary education most of them were not keen to teach literature because they were bound to the generalizations that technical students have no connection to learning literature. This is somehow on the contrary to what is mentioned by Carter and Walker (1989), Carter and Long (1990) in Ganakumaran, Shahizah and Koo (2003) that literature not only provide students with language enrichment but also with an opportunity to promote personal growth and development as well as greater sensitivity and self awareness towards better understanding of the world.

The data also showed that short story can be a good source to promote students' ability to generate ideas in writing reaction paper because students will be guided throughout the process of preparing their reaction paper where they will be having a sample text in hand and can be referred to from time to time. However, some considerations must be made on the use of short story for instance on the choice of material; with local setting or western, the length of the story and also the language difficulty of the texts. One of the ideas that can also be considered was to use videobased short story because it can be a good start to attract students' interest to appreciate the use of short story and also to appreciate literature as a whole.

As responded by the English Lecturers, literature can be introduced as a component in the teaching of English language to technical students. This can be a good way to develop language skills among technical students to enable them to perform effectively in their own field of study. Though, video clip has been regarded as more suitable in enhancing students' ability to write their reaction paper, English lecturers 
also found that short story can be a good source to help students in developing their language competency as well as to promote reading habit among technical students.

\section{DISCUSSION AND CONCLUSION}

The study was carried out in order to investigate the potential of using short story in enhancing students' reaction writing skills and also to study lecturers' perceptions on the use of short story in enhancing their students' reaction writing skills. Simple statistical analyses were done based on the pre-test-treatment-post test design of the study in answering research question one. It was proven that the design have benefited the students in guiding them to write their reaction paper. Out of 21 respondents $(\mathrm{N}=21), 71.4 \%$ (15 respondents) were able to include the three fundamental characteristics of writing good reaction paper in completing their tasks. The treatment sessions had obviously guided the respondents in integrating The Reader Response Approach, where when they were able to relate their personal experiences with what they read, in particular the short stories, the respondents were able to understand the meaning of the text. Respondents were able to relate what they read to their schemata and personal background in making profound impact and reactions of how they see and understand the world. This is in line with the idea proposed by Duarte (2010) in her study that by reading a short story, students will be able to relate and interpret the meaning by relating their personal experiences with what they are reading.

The survey done among technical students have shown that there is a possibility to introduce literature as one of the topics in the English language course and short stories can be a good resource to enhance students' ability to write reaction paper. It was found that technical students were not interested in reading activities and by using short stories, students' interest towards reading can be enhanced. Hence, the use of short story can help students' interest in learning literature where their language skills can be better enhanced and enriched (Pardede, 2010).

Although, the lecturers were not in a consensus that literature should be made compulsory to polytechnics' students, it was agreed that literature should be included as one of the component of the syllabus for English courses taken by technical students in addition to other language skills. The lecturers also agreed that it is necessary for technical students to learn literature as it can help them to improve their language skills. However, there were some issues that needed attention in regards to the incorporation of literature component, in particular, the use of short story to technical students. The choice of texts as well as the types of genre to be used in the lessons should be carefully considered. As mentioned by one of the interviewee, if short story is to be used in the English language course, it is suggested to consider the use of short story in the form of video presentation rather than a reading text since reading is something which is not favoured by the students. The respondents also indicated that the use of texts which are related to their field of study can be some of the options as well as the use of texts with characters and themes which are appropriate to their age limit. 
Literature can be introduced as a component in the teaching of English language in technical colleges. This can be a good way to develop language skills among technical students which has been regarded as more suitable in enhancing students' ability to write reaction paper. Short story can be a good source to help students in developing their language competency as well as to promote reading habit among technical students.

\section{REFERENCES}

Carlisle, A (2000). Reading Logs: An Application of Reader-Response Theory in ELT. ELT Journal. Volume 54. January 2009

Carter, R.A. and M.N. Long (1991). Teaching Literature, Essex : Longman in Saraceni, M (2007). Literature in the EFL Classroom : Roses or Thorns? in Teaching of Literature in ESL/ EFL Context. Kuala Lumpur, Malaysia : Sasbadi Sdn. Bhd. $13-26$

Creswell, J. W. (2008). Educational Research (Third Edition), Planning, Conducting, and Evaluating Quantitative and Qualitative Research. Pearson Educational International.

Da Silva, R. (2001). Using Literary Texts in the ESL Classroom. Retrieved on January 30, 2013 from http://www.cch.ufv.br/revista/pdfs/artigo8vol1-2.pdf

Duarte, E. G (2010). The Reader - Response Theory as a Pedagogical Tool in ELT. Paper presented at ELT Conference 2010. Retrieved from http://www.britishcouncil.org/colombia-ingles-elt-conference-2010presentaciones.htm

Erkaya. O.R. (2005). Benefits of Using Short Stories in the EFL Context. Asian EFL Journal. Volume 8, $1-13$

Galda, L., \& Liang, L. A. (2003). Reading as experience or getting the facts? Stance and literature in classrooms. Reading Research Quarterly, 38(2), 268-275.

Lazar, G (1993). Literature in the Language Classroom. Cambridge: Cambridge University Press, 180 - 185 in

McKay, S (1982). Literature in the ESL Classroom. TESOL Quarterly. Vol 16, No. 4 (Dec., 1982), pp 529-536

Pardede, P. (2011). Using Short Stories to Teach Language Skills. Journal of English Teaching. Volume 1, Number 1: $14-30$

Sanchez, H.S. (2009). Building Up Literary Reading Responses in Foreign Language Classroom. Journal of ELTED. Volume 12, Winter 2009.

Saraceni, M (2007). Literature in the EFL Classroom : Roses or Thorns? in Teaching of Literature in ESL/ EFL Context. Kuala Lumpur, Malaysia : Sasbadi Sdn. Bhd.

Scoggins, R. (2015). How to Write a Reaction Paper. USA: Georgia State University

Sidhu, G.K (2003). Literature in the Language Classroom: Seeing Through the Eyes of Learners in Teaching of Literature in ESL/ EFL Context. Kuala Lumpur, Malaysia : Sasbadi Sdn. Bhd. 88 - 110 
Sivapalan, S., Idrus, H., Bhattacharyya, E. and Nordin, S (2008). Engineering Students' Perception of the influence of young adult literature on developing appreciation for reading in The English Teacher Vol. XXXVIII: 27 - 39

Subarna Sivapalan, and Ganakumaran Subramaniam, (2008) The incorporation of literature in the English Language Programme for Engineering Students: learner interest and perception. 3L; Language,Linguistics and Literature,The Southeast Asian Journal of English Language Studies., 14 . pp. 45-73.

Subramaniam, G (2003). Literature Programmes in Malaysian Schools: A Historical Overview in Teaching of Literature in ESL/ EFL Context. Kuala Lumpur, Malaysia : Sasbadi Sdn. Bhd. $27-48$

Traore, M. (2011). Using Literature in the Business and Medical English: A Case Study in English for Specific Purposes World, Issue 36, Vol. 12, 2012.

Tucker, L.P (2000). Liberating Students through Reader-Response Pedagogy in the Introductory Literature Course. Copyright by the National Council of Teachers of English : 199 - 209

Widdowson, H.G. (1975). Stylistics and the Teaching of Literature. London: Longman in Saraceni, M (2007). Literature in the EFL Classroom : Roses or Thorns? in Teaching of Literature in ESL/ EFL Context. Kuala Lumpur, Malaysia : Sasbadi Sdn. Bhd. 13 - 26

\section{Keynote Speech}

Subramaniam, G (2012). Literature \& English Language Education: What art thou?.Keynote speech during a Seminar ESL Academic Discourse: Literature in English. Universiti Pendidikan Sultan Idris Perak. 20 October 2012 